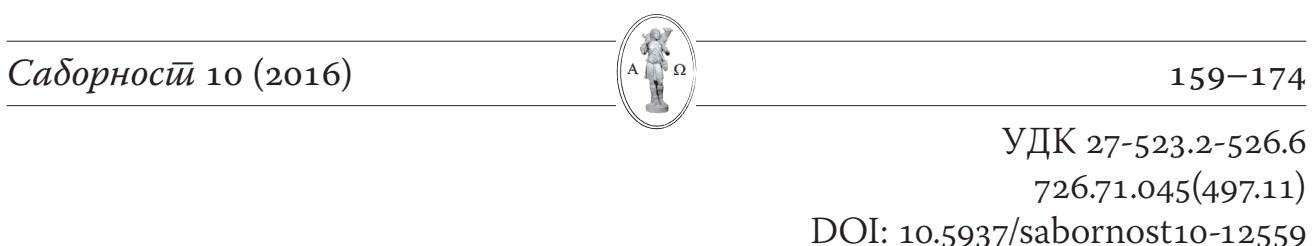

DOI: $10.5937 /$ sabornost10-12559

Прегледни чланак

\title{
Живојин Андрејић
}

Центар за митолошке студије Србије, Рача

\section{Златна - рајска врата у хришћанским храмовима}

\begin{abstract}
: У раду се доказује да је хришћански храм и персонификација Раја и да је, сходно томе, био опремљен позлаћеним вратима - Златним вратима. Открива се, на основу сачуваног ктиторског модела, да је и црква Св. Тројице деспота Стефана у Ресави имала Златна врата. Такође, златна врата су имале и многе друге велике српске задужбине.
\end{abstract}

Key words: Рајска врата, Златна врата, Св. Тројица у Ресави, деспот Стефан, Цариград, Венеција, Фиренца.

$\prod^{\mathrm{s}}$

равославни храм симболише тело оваплоћеног Логоса, покрет „нагнутог неба“ ка земљи, уобличење Оваплоћења у облику крста.

Хришћански храм и његова архитектура су, заправо, модел хришћанског космоса, а његов „осликани иконографски програм - у потпуности подударан с грађевином - јесте модел свијета удвојен у 'слици' свијета“, заправо, филозофска слика света - ликовна транскрипција речи. Хришћанско-православна филозофска значења су уграђена при пројектовању храма у просторну хијерархију. У вертикалној подели црквеног простора успостављена је духовна хијерархија кроз уздизање до Небеског Јерусалима, који симболизује простор куполе чија калота, као највиша и најсветија, припада Христу Пантократору.

Црква је, дакле, сматрана сликом космоса, а купола као символ неба над небесима у чијем простору борави небески цар: „И гледај те начини све по слици која ти је показана на гори“ (Излазак, XXV, 40). Мојсијев храм, старозаветна скинија, подигнут је према слици васељене и представља универзални модел. Тако је хришћанска црква идеалан храм као персонификација идеалног света на земљи, слика микрокосмоса у чијој калоти је стан Христов, престо Господњи.

mitcentar@open.telekom.rs 
160 |Андрејић, Ж., Злайна - рајска врайа у хришћанским храмовима

На тај начин је место где се врши хришћанско богослужење постало образ Цркве и симбол света обновљеног и преображеног у Христу у коме сам Бог обитава. Од најстаријих времена црква се називала Дом Божији, Дом Господњи и Дом молитве.

Храм је оса у којој се спајају небо и земља и земља и доњи свет. Према Јосифу Флавију, три дела храма представљају три васељенска предела: трем доње пределе и море, светилиште земљу и њене пределе а светиња над светињом небо. (Kuper, 1986, стр. 50)

У хришћанској симболици човек се сматра „храмом Божјим“. Заправо, каже се: „Христ, истински храм у који треба да уђемо... Храм Божји је обликована реч Божија. У храму Светог Духа подучава се реч Божија... Морамо да ступимо у храм Исуса Христа упркос свим покушајима ђавола. (Biderman, 2004, стр. 117-118) Уколико се храм може сматрати местом блаженства људи који свој живот проводе у досезању вере и праведности онда је он и рајски простор.

Хришћански храм није само симболично место Божијег обитавања већ и место богослужења и сабрања заједнице верника. Новозаветни храм је, пре свега, свештени простор за вршење Литургије. Унутрашњи распоред служи литургијским потребама Цркве и условљен је њима. Свети олтар са светом трпезом служи за вршење свете евхаристије која је симбол гроба Господњег, извора васкрсења. Лево у олтару је проскомидија - прво образ Голготе а потом витлејемске пећине рођења — „дом хлебова“ - где се припремају часни дарови. Десно се налази ђаконикон где се чувају свети сасуди и одежде. Олтарски простор - светилиште - одвојен је од централног дела храма - наоса - где се окупља народ, једном ниском преградом - иконостас - са троје врата. У западном делу храма се налази пронаос - нартекс - улазни простор у храм који је намењен за стајање верника и покајника. У касније време се овај простор поделио на два дела: унутрашњи нартекс, где су вршене литије и богослужења дневног круга и спољни нартекс - ексонартекс. (Фундулис, 2004, стр. 23-24)

Хришћанско-православни храм има четвора врата:

1. Царска врата, света или велика, налазе се у средини иконостаса, јер кроз њих излази Цар славе да би вернике нахранио Својим Телом и Крвљу. Света су зато што воде право ка Светом престолу - Часној трпези. Кроз њих не сме проћи ни једно непосвећено лице. Називају се и Красна врата и као таква су богато украшавана златом. Царска врата - Царске двери су знак Рајских двери која су „за читав људски род била затворена све док их оваплоћење Сина Божијег и јеванђеоска проповед за овоземаљске грешнике и вернике нису поново отвориле“. (Стошић, 2006, стр. 191) Кроз њих се износе и свети Дарови. Заправо то су врата Истока.

2. Северна врата која воде у део олтара где се налази жртвеник. 
3. Јужна врата - подневна врата воде у део олтара где се налази Ђаконикон.

4. Лепа - Црквена врата се налазе на западној страни храма, насупрот олтару, и воде у припрату, или директно за свечане изласке из храма. (Beлики ӥравославни боїословски енциклойеgијски речник I, 20оо, стр. 232)

Схема и симболика четворо врата окренутих на све стране света је давно успостављена. Врло сликовит пример из ранијих времена представља Диоклецијанова палата у Сплиту. Колико је познато њена најстарија и најимпозантнија су северна - главна - Златна врата /Porta aurea/, из 305. године. Источна су била Сребрна врата /Porta argentea/, западна су Гвоздена /Porta ferrea/ а јужна су била Бронзана врата/Porta aenea/. (Rodgers, 2006, стр. 350-351)

Врата храма означавају границу световног и профаног, односно границу између двају светова, између познатог и непознатог, светлости и таме. Улазна врата на храмовима су пролази светих ходочашћа која воде до светилишта над светилиштима, до места истинске присутности божанства. И сам храм има симболику врата - врата неба. Прелази са земље на небо иду кроз врата сунца кроз која се ступа у небеско краљевство. У хришћанском предању важност врата је огромна јер омогућавају „приступ објављењу“ и зато што изражавају хармонију универзума. „Врата“ Старог завета и Откровења, Христ на престолу и Последњи суд дочекују ходочаснике и вернике. Лепота која просвећује душе мора их упућивати ка светлости, светлости којој права врата представља Христ. (Chevalier, Gheerbrant, 1987, стр. 763-764) Учење вере упућује на то да је Христос себе идентификовао са „вратима“ и да нико не може да дође до Господа Бога сем кроз њега. Тако „Света врата“ сећају на пролаз од греха ка милости. Када се отворе посебна „Света — Рајска врата“ која су „украшена са 16 библијских призора" и препрека ка Господу је отворена. Један од најважнијих симболичких чинова сваког верника или хришћанског ходочасника је пролазак кроз четвора Света врата на дан Васкрсне недеље.

Врата су у хришћанском свету најпре слика и симбол. Православна црква поставља врата, врата храма и врата иконостаса, уз низ богослужења а тумачи их највише као видљив израз мистерије обожења и спасења. Она су улази у Царство, у небо, у рај и Небески Јерусалим. (Радујко, 1993, стр. 42) „Рајска врата нам отвори“ Господе. Тако су Рајска врата постала Златна врата.

Појавило се схватање у средњем веку да су златна врата на улазу у Рај. Традиционално Рај се поима као велико боравиште праведних и безгрешних. На почетку света то је ограђени простор - пошумљени врт - Едем у који су насељени Адам и Ева. Едемски врт означава место велике лепоте, савршенства и духовног блаженства и среће. (Исто, стр. 547-548) 
Пошумљени врт у коме је Бог населио Адама и Еву је назван Едеме Рај. Тиме је означено место велике лепоте, савршенства и духовне среће.

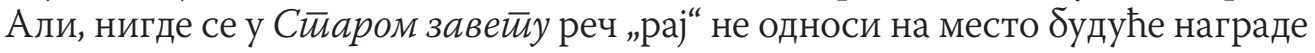
за праведнике. У Новом завету јавља се три пута али увек означава или указује на небо (Лк 23, 43; Кор 12, 4; Отк 2, 7). Апостол Павле покушава да поистовети рај са трећим небом у које је био узнесен у својој визији (Кор 12, 4). Традиционално схватање рај сматра великим боравиштем праведника. (Ракић, 1994, стр. 162-163) Док је боравио у земаљском Рају, Адам је био у наднаравној милости.

У призору Последњег - Страшног суда, завршном чину историје света, у којој ће Христос, при свом другом доласку у слави, наступити као судија ускрслог целог људског рода и разлучити га по заслугама да ужива вечно блаженство - рај или на вечну казну - пакао. У композицији Страшног суда праведници стоје у групама у Рају, блажени и одевени, а осуђени су голи. (Ivančić, Badurina, 1990, стр. 475-476)

Васкрсењем Христовим је „обновљен рај на земљи и враћена бесмртност роду људском, јер је бићу људском завршно и вечно дат сам Бог у личности васкрслог Богочовека Христа, у телу његовом свеживотворном - Цркви, која охристовљује, обогочовечује све кроз свете тајне и свете врлине“. Тако ће Господ на Страшном суду одвојити праведнике од неправедника а потом ће „праведницима доделити вечно блаженство у Царству Божјем“. А шта наступа тада и шта је то? Одговор је: „Рај, блаженство, царство Божије, Богочовечанско тело Цркве Христове, неисказана радост, вечна и безгранична“. (Поповић, 2004, стр. 800, 805, 808)

Насупрот Рају је Пакао - Ад - место мртвих. Христос је у време страдања на голготском крсту сишао у ад где се кратко време прикључио општем загробном стању за све умрле и потом срушио старозаветну силу „ада“ која је владала над свеукупним човечанством. Тек у новозаветно време Пакла постаје место казне, мучења и патње за грешне. У Пакао се улази кроз врата пакла која су заправо метафора. (Велики йравославни боїословски енциклойеgијски речник I, 20о0, стр. 27)

По традиционалним схватањима злато је савршен метал. Пошто је савршено оно симболизује почетно доба света - златно доба. Због изједначавања злата са сунчевом светлошћу оно је један од симбола Исуса - Светла - Сунца - Истока. (Исто, стр. 792-793) Као изузетно племенит метал злато је симбол чистог светла, небеско „почело у којем живи сам Бог“. (Ivančević, Badurina, 1990, стр. 592)

Царска врата - Царске двери - Рајске двери су „за читав људски род била затворена све док их оваплоћење Сина Божијег и јеванђеоска проповед за овоземаљске грешнике и вернике нису поново отвориле“. 
Златна - рајска врата на хришћанским црквама отварају могућност да храм персонификује Рај.

Остало је потпуно непознато како су изгледала и од чега су била израђена аутентична врата цркве Св. Тројице деспота Стефана у Ресави а којих је било укупно седам. Тако ништа не знамо о главним вратима, оним на припрати и улазу у наос цркве Св. Тројице. Константин Филозоф не описује ближе изглед цркве Св. Тројице, објекте у граду као ни саму тврћаву. О томе ћуте и потоњи извори. Без двојঠе се сматрало и сматра да су врата наших средњовековних цркава била грађена искључиво од дрвета и само у појединим случајевима са одређеном декорацијом.

Нема сумње, данашња врата на припрати Св. Тројице су из новијег времена а на улазу у наос из XVIII или из прве половине XIX века. Врата су дрвена, од масивних храстових дасака.

Једини аутентичан изглед врата улаза у наос цркве у Ресави приказан је на моделу храма који држи деспот Стефан у ктиторском ансамблу на северној страни западног зида наоса. На репрезентативној ктиторској слици представљена је целокупна Стефанова фигура натприродне величине у раскошном орнату владара - деспота: дивитисион тамно црвене боје који је украшен ситним златовеженим орнаментима и коластим аздијама са двоглавим орловима, златан лорос, златне табуле и перибрахион на мишицима, плашт тамноцрвене боје са златним коластим аздијама и широким златним штитником који је закопчан испод врата, на глави има златну деспотску круну, у десној руци златни скиптар — крст са две пречке․ „Ни један српски владар није на портрету толико истакао свето порекло своје власти као Стефан Високи у Манасији... Осим овог очуваног портрета морало је у манасијској цркви бити још деспотових фресака. Сигурно је над гробом /као у Љубостињи/ била надгробна слика... Врло је чудновато, да се ни у Манасији не налази портрет жене Стефана Високог; деспот се женио септембра 1405, а манасијски живопис рађен је после тога датума“. (Радојчић, 1996, стр. 70-71) У левој руци деспот држи доста велики модел своје ктиторије која је насликана без припрате тако да се јасно види западна фасада са вратима и каменом розетом изнад њих. И поред тога што је била пројектована камена розета није постављена. Тако је ова непостојећа розета привлачила највећу пажњу истраживача. О вратима није било речи.

Из тих разлога је остало не примећено како су представљена улазна врата храма у Ресави. Њих чини једноставан камени оквир са архитравом и плитком нишом над њима. Међутим, на слици модела цркве који држи деспот Стефан врата нису боје дрвета или слично. Остало је потпуно

1 Више о ктиторској композицији, види наша запажања у Андрејић, 2009. и Андрејић 2011. 
непримећено у нашој историји уметности да су насликана златном бојом. Осим, тога сасвим добро се разазнаје да су вратнице украшене са по пет квадратних касета. Укупно десет касета. Поља касета су равна и као да нису имала рељефне садржаје. Међутим, може бити и супротно, да су врата на Св. Тројици била рељефна.

Постављено је и питање колико се поверења може дати сликарима ктиторских модела цркава, колико су одговарали стварном изгледу саграђених храмова, да ли су у питању пројектни модели или слике саграђене цркве? Један од одговора је да су у питању слике финалног изгледа саграђене цркве. „Самим тим, сликане грађевине у рукама ктитора морале су бити a posteriori евокације изведене грађевине. Недостатак писаних или визуелних сведочанстава упућује нас на опрез и спречава да ово са потпуном сигурношћу тврдимо“. (Маринковић, 2007, стр. 87) Постоје тврдње да су сви сликани модели цркава у ктиторским композиција настали тек после изградње и да доста верно приказују њихов најстарији изглед. (Исто, стр. 87, 89)

За ктиторски модел ресавске цркве се каже да „због велике прецизности представљене архитектуре има важност документа“. (Исто, стр. 156) То би значило да су грађевина и детаљи цркве Св. Тројице врло реално и верно представљени. Када су у питању портали насликаних цркава у ктиторским ансамблима они су обично увећани те се, као и неки други делови, могу сматрати симболичним елементима. Такав је случај и са Манасијом. Занимљив је нереалан опис Ч. Маринковић изгледа врата цркава: „Врата која затварају портале састављена су из више декоративних поља браон боје“. (Исто, стр. 70)

У сваком случају, „иконографија врата није систематски истражена“.

Најзначајнији досадашњи покушај реконструисања изгледа и конструкције врата наших средњовековних цркава, а све на основу сликаних ктиторских модела, учинио је Слободан Ненадовић и то, понајвише, на основу ктиторског модела цркве манастира Леснова и Краљеве цркве у Студеници: „Двокрилна улазна врата можда је имала и црква манастира Леснова... Тај модел нам говори врло много и о самој конструкцији тих крила: она су била састављена од рама, који се гради од дасака; квадратна поља у раму затварају се тзв. испунима и таква се врата називају столарским вратима... јер су се крила окретала око оне осовине коју су образовали испусти у облику чепова на горњој и доњој страни, а прислањала су се уз камени зуб... У ретким случајевима удубљење за осовину, односно чеп крила у поду, појачавано је још и са гвозденим лежиштима... У народу таква врата називају се 'врата на жујице'... У том погледу нарочито се истиче модел Краљеве цркве у Студеници; на њему су насликана двокрилна врата, која су грађена на исти начин са испунима, само су била једноставнија. Врата су насликана жутом бојом... То је боја коју су сликари 
употребљавали када је представљано дрво. Свако крило врата имало је и алку, са којом је привлачено приликом затварања... вероватно је да су ова врата била без икаквог дуборезачког украса, али је тешко веровати да би монументални споменици, као што су били Богородичина црква у Студеници, Бањска, Дечани Св. арханђели код Призрена могли имати главна улазна врата само са таквим једноставном обрадом. Далеко је вероватније да су и та врата била ठогато обрађена на начин као што су врата мајстора Андрије Бувине...". (Ненадовић, 1966, стр. 26-28)

Међутим, неуверљива је тврдња Ненадовића да су дрвена врата, која су иначе тамне боје, била приказивана у фреско живопису окер-жутом бојом. Насупрот томе, уверљива је Ненадовићева тврдња да српски монументалне цркве нису имале једноставна главна врата већ богато украшена попут врата катедрале у Сплиту мајстора Андрије Бувине.

Филозоф каже да је деспот дао да се црква живопише од стране најбољих мајстора са разних страна сабраних: „многим златним и цветним шарама /украси је/“. Деспот „ризнице овде из дана у дан полагаше. Начини ту себи гробницу, где ускоро би положен. Даде и драгоцене иконе украшене бисерјем и златом, снабде сваким књигама за богослужење, /приложи/ толико много служабних одежди и црквених сасуда са великим бисерјем и златом украшене да превазилази и изабране велике лавре Свете Горе... И шта прво да споменем /од онога/ што овде принесе и украси... у све дане живота свога никада не престаде да приутврђује различитим и најбољим даровима и надгледањем“. (Филозоф, 1989, стр. 103-104) Византијско плаво, бисери и злато. Свуда се помиње злато. Нажалост Константин Филозоф није знао од дивљења да нам поброји све оно чиме је деспот украсио своју ктиторију.

Врло важан податак о односу деспота Стефана као ктитора и дародавца великих лаври представља детаљ из његове повеље манастиру Св. Атанасија на Атосу, 2о. јануара 1427. године. Деспот Стефан је затражио да му после смрти одржавају помен у Великој Лаври а заузврат је манастиру дао два сребрна и позлаћена свећњака од шездесет литара /око 20.280 кг/. (Младеновић, 2007, стр. 264) Овај податак нам говори у прилог тврдње да је на својој ктиторији богато украсио улазна врата али и да је реално тврдити да ју је опремио и са златом украшеним иконостасом, свећњацима и полијелејом.

Дакле, своју цркву У Ресави деспот Стефан је могао опремити богато украшеним главним вратима. Заправо, то су могла бити дрвена или бронзана врата са позлатом - Златна врата. 


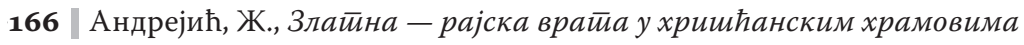

Нема сумње да се деспот угледао на Раваницу, задужбину свога оца Лазара, приликом градње своје цркве у Ресави: „Већу и лепшу ја ћу подићи“. (Филозоф, 1989, стр. 87) Данас знамо да је његов узор била и црква Св. Арханђела цара Душана. Дакле, ако је деспот превазишао ове велике задужбине онда би то значило да су, поред осталог, ове цркве имале слична украшена врата - Златна врата. И данашња врата Богородичине цркве манастира Раванице су из млађег периода. Ктиторски модел Раванице је оштећен и не показује нам јасан изглед врата. Али, шта кажу извори како је изгледала Раваница. Компетентни патријарх Данило III тврди: „Он из основа сазида манастир звани Раваница, а прекрасну цркву подиже у име Вазнесења Господа и Спаса нашег Исуса Христа... Божанствену цркву прекрасним мермером улепшавши, а сребром и златом божанствене иконе наслика. Не само иконе, него и зидове златом наслика“. (Јовановић, 2ооо, стр. 75) Непознати Раваничанин нам даје додатне информације о Лазаревој задужбини: „Подиже /Лазар/ храм... на месту званом Раваница, висином и лепотом што задивљује и на четири стуба утврђен... Златом и различитим бојама украси и различитим сасудима сребрним и позлаћеним обогати га... дверца /царска/ сребрна позлаћена, свећњаке на исти начин, иконе велике и мале оковане и позлаћене и бисером и камењем драгим украшене, завесе разне од висона, порфире и злата изаткане“. (Трифуновић, 1989, стр. 12-13) Дакле, у Раваници је било свуда сребра а поготову злата. Иако се не помињу, полијелеј и врата Раванице су била на исти начин украшени, позлатом.

Други деспотов узор, Св. Арханђели код Призрена су срушени скоро до темеља а нема никаквог њиховог описа у изворима.

Деспот Стефан се могао угледати и на велелепне Дечане, из 1343. године. Давно је примећено да деспотов ктиторски портрет са моделом и свитком са посветом доста наликује на портрет краља Стефана Дечанског у Дечанима. И испод модела краљеве цркве у Дечанима се протеже ктиторов заветни текст. Краљ Стефан Дечански у свечаном владарском орнату, са богато украшеним дивитисионом: златан лорос, златне табуле и перибрахион на мишицама, широким златним штитником и на глави златна круна која наликује деспотској. Обема рукама држи модел цркве али се јасно види да врата Дечана нису осликана златном бојом већ крем-белом. (Маринковић, 2007, стр. 266) На моделу Дечана, који држе краљ Стефан и његов син краљ Душан, на јужном зиду наоса, врата се не виде пошто је приказана источна страна цркве. (Исто, стр. 265, 290) То значи да велелепни Дечани нису имали првобитна врата од бронзе или са позлатом. Крем бела боја врата упућују да су била од сребра или од посребрене бронзе.

Али, на ктиторском моделу цркве Св. Ђорђа манастира Леснова коју је градио царски деспот Јован Оливер, 1346-1347. године, примећујемо окер-жута врата са по три касетиране вратнице. Може се реално 
претпоставити да су у питању бронзана врата са позлатом. (Исто, стр. 269) У прилог иде и чињеница да је деспот Оливер у својој земљи имао богате злетовске руднике злата. А и да је ковао самостално свој сребрни новац.

И врата на моделу невелике Богородичине цркве манастира Трескавац, који држи тепчија Градислав, из 1350. године, јесу окер-жуте боје. У питању су једнокрилна врата са три касете а друга са две. (Исто, стр. 271) Чини се да су окер-жута двокрилна врата насликана и на цркви Успења Богородице у Матејчу, царице Јелене и цара Уроша, 1355-136о. године. (Исто, стр. 273) Светлом окер бојом су насликана и двокрилна врата на цркви Св. Николе у Псачи, 1367-1371. године. (Исто, стр. 275)

На ктиторском моделу Богородичине цркве у Студеници - Краљева црква, 1314. године, јасно се виде врата насликана окер жутом бојом, попут боје златовежених делова свечане краљевске одеће. (Исто, стр. 249)

И на ктиторском моделу Грачанице који држи краљ Милутин, око 1318. године, запажамо да су приказана двоја врата, западна и јужна, али осликана златном бојом, попут златних украса на свечаној владарској одећи. Вратнице имају по две касете, види се јасно, без икакве декорације. (Исто, стр. 253) Готово је потпуна сличност са осликавањем златних врата деспотове Ресаве.

Нема сумње да је и на обновљеној Богородичиној цркви манастира Хиландара краљ Милутин, поставио бронзана врата, а може бити и позлаћена, 1293-130о. године. Данашња врата на улазу у наос Хиландара су из 1639-1640. године. (Петковић, 1989, сл. 46)

Врло би занимљиво било да су сачувана оригинална врата Богородичине цркве у Студеници, најстарије ктиторије, великог жупана Симеона Немање, родоначелника династије, из 1184. године. Није сачуван ни најстарији ктиторски портрет Симеона Немање са моделом цркве. Али, на доста нетачно сликаном моделу цркве коју држи велики жупан Немања као монах Симеон, из 1568. године, по свему су приказана дрвена двокрилна врата. (Маринковић, 2007, стр. 284) То и није чудно ако се има у виду да је Студеница већ сто година под турском влашћу, да је манастир опљачкан и да су ово нова и скромнија врата. Уколико се има у виду да је Богородичина црква у Студеници богато сликана и да је живопис украшен: „Најскупоценијим украсом са златном позадином на којој је имитирана техника мозаика, са златним ореолима и златним везом на одећи архијереја... Златни натписи и ореоли постављени су и у наосу... расуо је златне звезде по плавој позадини Распећа.... Живописање и комплетно опремање је извршено тек после смрти Симеона Немање, после 1199. године. (Бабић, Кораћ, Ћирковић, 1986, стр. 70, 73, 10) Заправо, из златом писаног текста у прстену куполе, дознајемо да је Студеница осликана 1208-1209. године. (Мандић, 1956, стр. 39, цртеж 2) 


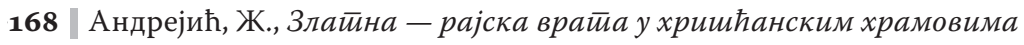

Фрагменти позлаћене бронзане оплате са врата цркве епископије Мораве, потоње епископије Браничево, откривени су у данашњем Куличу. Словено-српско племе Морављани је на простору некадашњем римског града Маргума засновало свој велики центар у коме је било и седиште епископије кнежевине Морава. Оплата је украшена фантастичним животињама. Пронађени су и бронзани крстови. Остаци прероманичке цркве и некрополе откривени су на потезу Орашје. (Миленковић, 1996, стр. 169-172) На читавом простору некадашњем града и тврђаве Морава налажени су остаци који се датују у период од X до XIII века. (Jacanović, Spasić-Djurić, 2003, стр. 39)

Постоје још две велике српске задужбине и лавре чији је живопис био украшаван златним плочицама и у складу са тим би се могло претпоставити да су имала богато украшена дрвена или бронзана врата са позлатом. То је црква у Жичи, црква Христа Спаса - Вазнесења Христовог, која је била прва српска архиепископална црква, и такође, црква Вазнесења Христовог манастира Милешеве. Обе цркве су биле сактиторије првог српског архиепископа Саве, Жича са Стефаном Немањом II Првовенчаним а Милешева са краљем Стефаном Владиславом I.

И архиепископална црква у Жичи је била богато украшена позлатом и опремљена исто тако луксузно украшеним иконостасом, свећњацима и полијелејом. Краљ Стефан Немања II Првовенчани каже да је са својим сином Радославом цркви Спасовој у Жичи даривао бројне делове и честице мошти највећих светитеља, а потом иконе светих и часних ликова и сасуде златне и сребрне и рипиде многе и завесе и покрове свете и ризе часне и света јеванђеља и књиге многе и друге украсе. (Првовенчани, 1988, стр. 109) Осим тога, до крунисања краља Радослава, 1228. године, извршена је доградња спољне припрате са кулом на прочељу и катихуменом на спрату за архиепископа Саву I. (Чанак-Медић, Тодић, 2007, стр. 6-7, 46)

Програм живописа и ентеријер Милешеве био је јединствено спроведен великом употребом златних листића на позадини фресака постављених попут коцкица мозаика са намером да се дочара небеска светлост и светост „од куполе па све до спољне припрате“. (Кандић, Поповић, Зарић, 1995, стр. 51) Ово украшавање је плод обнове који су извршили краљ Владислав I и архиепископ Сава I који се припремао за свој други пут у Јерусалим. Заправо, обнова живописа и доградња спољне припрате са катихуменом и две куле цркве Христа Спаса у Милешеви извршена је до 1235. године када је сазрела шира политичка одлука да Сава I буде почаствован титулом патријарха² у Јерусалиму. (Андрејић, 2004, стр. 91-128; Исти, 2008,

2 Не постоји ни један правоснажан разлог за силазак Св. Саве са архиепископског трона Српске цркве, 1235. године. До промене архиепископа је могло доћи само у случају смрти или детронизовања „због грехова“. Такав случај није био са Савом I, а то се недвосмислено види и из његових Житија. Када је Св. Сава стигао у Јерусалим патријарх Атанасије га / на Васкрс, 8. априла 1235./ „пророкова... пред лицем целог Сабора јерусалимског“, сас- 
стр. 81-82) За седиште партијарха Саве I била је предвићена и адекватно припремана милешевска црква Христа Спаса. Зठог изненадне смрти патријарха ${ }^{3}$ Саве у Трнову, 1236. године, Милешева није остварена као патријаршијско седиште. (Андрејић, 2015, стр. 267-290)

Имајући у виду све ово, треба претпоставити да је будућа патријаршија, црква Христа Спаса у Милешеви, морала добити и адекватне, са позлатом украшене иконостас, врата и полијелеј. ${ }^{4}$

Где је још деспот Стефан могао видети нека златна врата и пожелети их на својој задужбини? Постоје ли и друге аналогије за златна врата Св. Тројице у Ресави?

Зна се да је деспот Стефан био у великим културним срединама Истока, попут Цариграда, Солуна и Митилене. Нема сумње да је деспот Стефан у Цариграду, Солуну, Мистри и Митилени могао видети цркве са масивним дрвеним вратима која су била обложена бакром или бронзом са позлатом а која су касније уништена. ${ }^{5}$

луживаху заједнички Велику Литургију, „називаху га земаљским анђелом и небесним човеком... коме после светих не нађе равна“, у савећању га саветоваше над Христовим гробом и предаде му свете сасуде, свете књиге и „патријашке одежде“. (Види у: Доментијан, 1938, стр. 182-183, 185)

Доказ да је Св. Сава имао и титулу патријарха налазимо у фреско слици над патријаршким троном у Пећкој патријаршији, насталој у време архиепископа Арсенија Сремца, наследника Св. Саве, око 126о. године. Овај портрет светог Саве садржи натпис: „Свети Сава први патријарх“. Осим тога, Св. Сава је насликан са патријаршком калиптром, патријаршким сакосом и патријаршким крстом. (Види у: Ђурић, Ћирковић, Кораћ, 1992, стр. 236-238) Истоветан, оригиналан, позлаћени крст Св. Саве се чува у музеју у Пиенци код Сијене, у Италини, са натписом: „Сава први архиепископ и патријарх српски“. (Види у: Радојковић, 1977, стр. 81) У то време је настао и спис „О патријарсима српске земље“ у коме се тврди да је „први српски патријарх свети Сава“.

3 Доказ да је Св. Сава почаствован и титулом патријарха јесте и сам чин крунисања бугарског владара Јована II Асена за цара и освештавање Трнова за царски град ако се има у виду да чин посвећивања за цара може извршити само и једино патријарх. (Види: Дагрон, 2001, стр. 75, 317, 322-323)

4 Једина бронзана врата на српским краљевским задужбинама су на цркви Св. Ђорђа краља Петра Карађорђевића на Опленцу у Тополи, која је довршена 1930. године. Црква је украшена луксузним мозаиком од стаклене пасте и злата. Двери иконостоса су израђене од храстовине опточене сребром, огромни полијелеј је од бронзе а монументална двокрилна врата од масивне храстовине обложене бронзом. Оба крила врата су са по 10 касета у два реда у којима су рељефни двоглави орлови. (Недељковић, 1989, стр. 42-44)

5 У Цариграду: Св. Софија, Св. Апостоли, Св. Срђ и Вакх, Св. Ирина, Богородичина црква Константина Липса, Мирелеон, Богородица Памакаристос, Христ Пантепопте, Христ Евергетис, Христ Пантократор; Христа Хоре, Богородица Кириотиса. У Солуну: Св. Софија, Богородичина црква, Св. Апостоли, Св. Димитрије, Св. Катарина, Христа Спаситеља, Св. Илија. У Мистри: Св. Димитрије, Св. Теодори, Богородица Одигитрија, Богородица Пантанаса. 
Најславнија „златна врата“ Цариграда и Златног рога била су у оквиру тзв. Златне капије у јужном делу великог зида, у близини Мраморног мора. И о изгледу ових врата нема података, зна се само да је то Златна капија која је имала статус Прве војне капије и кроз коју је по традицији пролазио цар приликом церемонијалних улазака у град. ${ }^{6}$ (Рансиман, 1996, стр. 113) Да су у Златној капији Цариграда заиста била златна врата показује нам и мозаичка ктиторска слика царева Константина Великог, који држи макету града, и Јустинијана I, који држи цркву Свете Софије пред Богородицом са Христом, у лунети изнад њених јужних врата. На моделу Цариграда врата су од златних мозаик коцкица. Овај мозаик је постављен 994. године. На макети Св. Софије ни једна од врата нису приказана а на моделу града Цариграда је јако истакнута једна једина, главна капија која је сачињена од златних мозаичких коцкица. (Yerasimos, 2007, стр. 101)

Када је у питању црква Свете Софије у Цариграду њена оригинална врата на улазу у наос нису сачувана. Међутим, сачувана су оригинална јужна врата која су била постављена 839. године. Ова врата су од бронзе и са уметцима од сребра а састављена су од старијих плоча са плитко-рељефним мотивима грчког меандра и акантусовим лишћем. (Rani srednji vek, 1976, стр. 95)

Али, на моделу цркве Христа Хоре у Цариграду, коју држи њен ктитор велики логотет Теодор Метохит, 1315-1321. године, јасно се уочавају двокрилна „златна“ врата са по три касете. На моделу цркве врата су изведена златним мозаик коцкицама. (Маринковић, 2007, стр. 250)

Деспот је више пута боравио у угарском престоном Будиму, Пешти, Кежмарку, Баји и Сегедину који су припадали културном и цивилизацијском кругу Запада. Деспот ठорави у својој палати у Будиму, 1408, 1411, 1412, 1422, 1424, 1425. и 1426. године. (Пурковић, 1978, стр. 86, 101, 122, 124, 128, 132) Постоје тврдње да су деспотови изасланици боравили на сабору у Констанци $/ 1415 /$, (Исто, стр. 143-145) и на челу са војводом Витком у Венецији /1422/. (Исто, стр. 117-121) И ту су могли Срби видети цркве са ठронзаним рељефним вратима као и оне са позлаћеним рељефима.

Врата катедрале Св. Марије /познатије као Св. Дује/ у Сплиту су монументална и од дрвета. Дело су сплитског вајара Андрије Бувине из 1214. године и представљају једно од најлепших остварења романичке уметности уопште. Свака вратница има по 7 касета у два реда. Двадесет осам касета је уоквирено богатом декорацијом и на њима је приказан живот и муке Христове. Начин приказивања сцена јасно упућује на снажан утицај

6 Према словенској и турској традицији код Златне капије је погинуо последњи византијски цар Константин XI Драгаш, 29. маја 1453. године. Крај Златних врата је сахрањено „успавано“ царево тело које ће се пробудити и поново ослободити Цариград. Из тих разлога, из страха, Турци су наредили да се Златна капија зазида и никада више није отворена (Никол, 1997, стр. 108, 122-123) 
византијске иконографије. Врата и данас чувају остатке златне и црвене боје којима је рељеф и плетер био раскошно украшен. (Суботић, 1963, стр. 64-65)

Могући, најзначајнији узори за израду ресавских врата од злата могу се пронаћи и у сачуваним ठронзаним и позлаћеним вратима италијанског трећента и кватрочента, а која су настала пре или у време деспота Стефана.

Прва бронзана и позлаћена врата Баптистеријума у Фиренци израдио је Андреа Пизано до 1336. године. Друга бронзана и позлаћена врата за Баптистеријум, израдио је 1403. године Лоренцо Гиберти /1378-1455/. Ова врата имају вратнице са по два реда и по 14 касета /2 x 7/. (Bietoletti, Capreti, Chiarini, Cresti, Giusti, Morandi, Paolucci, Scalini, Tartuferi, 2005, стр. 23) Трећа бронзана и позлаћена „Рајска врата“ за Баптистеријум у Фиренци, Гиберти је израдио између 1425. и 1432. године. Микеланђело је сматрао да ова врата изгледају величанствено и да представљају улаз у рај. Трећа врата имају једноредно касетиране вратнице. Вратнице имају

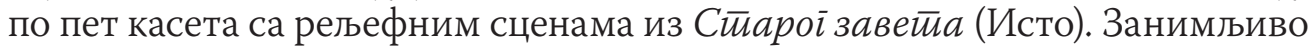
је да врата имају на почетку сцене које се односе на Рај: Сйварағе Agaмa и Еве и боравак у Рају, Кушање Аgама јабуком са дрветй знања добра и зла и Пройериване из Раја. 
172 | Андрејић, Ж., Злайна - рајска врайа у хришћанским храмовима

\section{Литература}

Андрејић, Ж. (2004). Свейи Сава. Рача.

Андрејић, Ж. (2008). Размишљање о датуму смрти Светог Саве према подацима Доментијана и Теодосија. У Известиија на Реіионален истиорически музеи, XXIII. Велико Тарново.

Андрејић, Ж. (2009). Истраженост стила живописа Манасије и порекла чланова сликарске тајфе деспота Стефана. Саборнос $\bar{u}, 3,297-317$.

Андрејић, Ж. (2011). Висока теолошка и идејна осмишљеност оријентације, архитектуре и живописа Св. Тројице у Ресави. Саборносй, 5, 181-205.

Андрејић, Ж. (2015). Милешева као неостварено патријаршиско седиште 'Саве првог архиепископа и патријарха српског'. Мийолошки зборник, 35, 263-294.

Бабић, Г., Кораћ В., Ћирковић С. (1986). Сйуgеница. Београд.

Biderman, H. (2004). Rečnik simbola. Beograd.

Bietoletti, S., Capreti E., Chiarini M., Cresti C., Giusti A., Morandi C., Paolucci A., Scalini M., Tartuferi, A. (2000). Florence Art and Architecture. Cambridge.

Велики йравославни боіословски енциклоиеедијски речник I. (20оо). Нови Сад.

Tartuferi, A. (2005). Florence Art and Architecture. Cambridge.

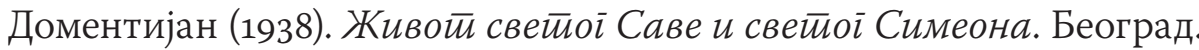

Ђурић, J.В., Ћирковић, С., Кораћ, В. (1990). Пећка йайријаршија. Београд.

Ivančić, R., Badurina, A. (1990). Leksikon ikonografije, liturgike i simbolike zapadnog kršćanstva. Zagreb.

Yerasimos, S. (2007). Constantinople. Paris.

Jacanović, D., Spasić-Djurić D. (2003). Margum. Požarevac.

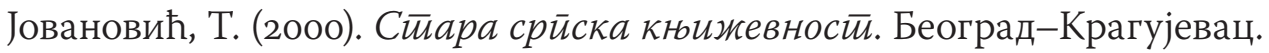

Кандић, О., Поповић, С., Зарић, Р. (1995). Манасӣир Милешева. Београд.

Kuper, K.Dž. (1986). Ilustrovana enciklopedija tradicionalnih simbola. Beograd.

Мандић, С. (1956). Откривање и конзервација фресака у Студеници. Сa-

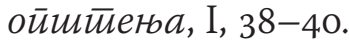

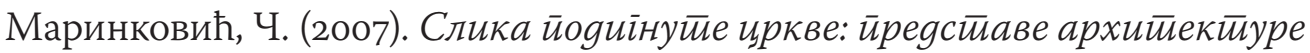

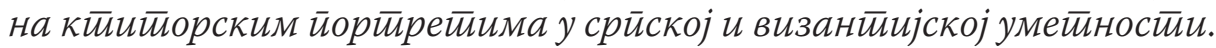
Београд - Крагујевац.

Миленковић, М. (1996). Позлаћена апликација са локалитета Орашје Црквина. Гласник САД, 11, 169-172.

Младеновић, А. (2007). Повеље и йисма gесӣойа Сйеффана. Београд. 
Недељковић, М. (1989). Тойола - Карађорђев іраg - Ойленац. Топола.

Ненадовић, С. (1966). Типови врата у народној архитектури. Zbornik zaštite spomenika kulture, XVII, 25-50.

Никол, Д. (1997). Бесмрйни цар. Београд - Бања Лука.

Петковић, С. (1989). Хиланgар. Београд.

Поповић, J. (2004). Доімайика Православне иркве, III. Ваљево.

Првовенчани, С. (1988). Сабрани сиичси. Београд.

Пурковић, М. (1978). Кнез и gесӣой Сйефан Лазаревић. Београд.

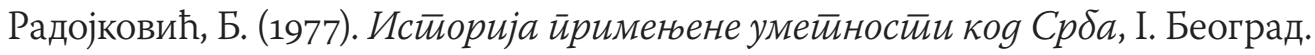

Радојчић, С. (1996). Порйрейи срйских влаgара у среgњем веку. Београд.

Радујко, М. (1993). Еклесијално-есхатолошки симболизам у евхаристијској тематици византијског уметничког круга. 3оірая, 23, 29-50.

Ракић, Р. (1994). Библијски речник. Београд.

Rani srednji vek. (1976). Beograd.

Рансиман, С. (1996). Паg Цариіраgа 1453. Нови Сад.

Rodgers, N. (2006). Roman empire. London.

Стошић, Љ. (2006). Речник ирквених йојмова. Београд.

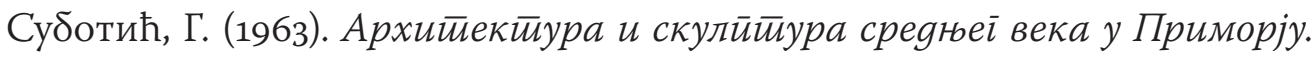
Београд.

Трифуновић, Ђ. (1989). Жийије свейоїа кнеза Лазара. Београд.

Филозоф, К. (1989). Жийије gесйойа Сйефана Лазаревића. Београд.

Фундулис, J. (2004). Литиуріика, I. Краљево.

Чанак-Медић М., Тодић Б. (2007). Манастиир Жича. Београд.

Chevalier J., Gheerbrant, A. (1987). Riječnik simbola. Zagreb. 


\section{Živojin Andrejić \\ Centre for the Mythological Studies of Serbia, Rača}

\section{Golden - Heaven's Doors in Christian Temples}

The door of a temple marks the border between the secular and profane. The to the shrines of sanctuaries, to the places of the true presence of the deity. Consequently, a temple itself is a sort of a door. 'The Holy Door' reminds of a passage from sin to grace and of reaching the Paradise on the Doomsday. Thus, a Holy Door is a Heavenly Door at the same time. It is the entrance to the heavenly Jerusalem, the Golden Gate. Conversely, a truly golden - gilded door into a Christian church converts a temple into Paradise. The most significant contemporary role models for making the golden door in Resava monastery can be found in Istanbul, Venice and Florence.

The authentic looks of the door entrance to the nave of the church of St. Trinity in Resava is shown on the model of the temple held by despot Stefan in his founder's ensemble. The door is painted the golden color like the despot's pieces of clothing, also of gold - gold embroidery. This is a solid proof that, whether they were wooden or bronze, the door to the church in Resava used to be plated - Golden Gate. Having analyzed the looks of other great foundations built by Serbian royalty, we have concluded that the "Golden Gates" were also present in the churches in monasteries such as Ravanica, Lesnovo, Treskavac, Matejca, Psaca, Gracanica, Hilandar, Mileseva, Zica and Studenica.

Key words: Heaven's Door, Golden Gate, church of St. Trinity in Resava, despot Stefan, Istanbul, Venice, Florence.

Датум пријема чланка: 7. 6. 2016.

Датум прихватања чланка за објављивање: 1. 12. 2016. 